\title{
Gender in Management
}

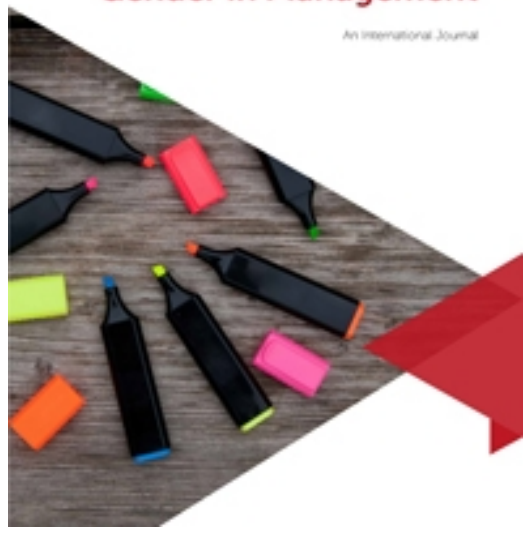

\section{'Gendering' Contamination: Physical, Social and Moral taint in the Context of Covid-19}

\begin{tabular}{|r|l|}
\hline Journal: & Gender in Management: an International Journal \\
\hline Manuscript ID & GM-06-2020-0172.R1 \\
\hline Manuscript Type: & Original Article \\
\hline Keywords: & Culture (sociology), Diversity, Health \\
\hline \multicolumn{2}{l}{} \\
\end{tabular}

SCHOLARONE $^{\text {TM }}$

Manuscripts 
'Gendering' Contamination: Physical, Social and Moral taint in the Context of Covid-19

\section{Introduction}

Heather Höpfl, in her illuminating chapter: Dirty Work and Acts of Contamination (Höpfl, 2012) starts with the well-known story of Mary Mallon, otherwise known as 'Typhoid Mary'. Born in Ireland in 1869, Mary worked as a cook for wealthy families in New York in the early 1900s where, in the course of her work, she contaminated up to 53 people with the typhoid pathogen. Suspected at the time of failing to wash her hands thoroughly before handling food, she infected the meals she prepared, leaving 'her fatal mark on everything she touched' (Höpfl, 2012: 19).

This is a story of contamination. Defined by the Oxford English Dictionary as 'the action or state of making or being made impure', contamination speaks to issues of pollution, dirt, infection and the spreading of contagion through bodily contact and touch. It is also a story about inequality, with dirt and pollution often associated with the working class (McClintock, 1995). Preparing and serving food - seen as potentially defiling through the need to handle messy raw materials such as vegetables and meat - have historically been undertaken by 'relegated' social groups, allowing the middle class to be 'stain free' (Simpson et al, 2012). Cleanliness, dirt and contamination therefore are seen as having a social and moral significance with avoidance rules often meaning that work dealing with physical dirt is carried out by those who occupy lesser positions in the social hierarchy.

In this short 'thought piece', with a focus on the current crisis around Covid-19, we consider the 'gendering' of contamination. We take 'gendering' to include, not just a focus on gender relations and gendered power, but other forms of inequality e.g. around class, ethnicity or occupation. These forms of difference and sources of inequality are likely to be interwoven, and we accordingly use the term 'gendering' in this broader sense to encompass a range of discrimination and disadvantage. In 
so doing, we draw on understandings of contamination (e.g. Douglas, 1966) and on the typology developed by Ashforth and Kreiner (1999) in their conceptualisation of physical, social and moral taint, to explore the 'gendering' of contamination in the context of Covid-19. We show that contamination is rooted in structural disadvantage, reproducing classed, gendered and racial difference in terms of how it is encountered and experienced.

\section{Contamination}

As Höpfl (2012) points out, contamination is about contact and contagion. It concerns the transmission of a physical or moral pestilence or disease, communicated from one body to another whether by touch or by exhalation. As a form of physical or moral corruption, it has potential to bring infirmity and potentially death, engendering a drive for immunization and desire to break or interrupt transmission. In that contamination can have both a physical and a moral dimension, it can also be seen as a state of 'disordered otherness' where blame is cast on particular 'disordered' people and practices. Thus, 'blame' for Covid-19 has been placed at the door of foreign governments and nationals. This has included China, thought to be the source of the outbreak and party to a government sponsored 'cover up' (Karyotis, 2020), as well as incoming, infected Italian and Spanish tourists who, in the early stages of the outbreak, arrived unmonitored into the UK (Lay, 2020). As this suggests, and as exemplified by Typhoid Mary above, it is the disordered body of the 'other' which is often seen as the agent of transmission.

This notion of contamination as 'disorder' and 'otherness' originates in the work of Mary Douglas (Douglas, 1966) who, in her ground-breaking book Purity and Danger, suggests that dirt is a violation of order and 'matter out of place'. To maintain the purity of an order, boundaries have to be drawn to keep the clean from the danger of contamination. Cleanliness therefore involves a set of practices that can become ritualised (social distancing, handwashing, the wearing of masks), which centre on people (re) establishing boundaries, separating the pure from the contaminated and imposing a cultural system on an 'inherently untidy experience' (Douglas, 1966). 
Here the regulation and 'ordering' of contamination contains a kind of purity, in specifying right and proper behaviours and in the reliance on rational, 'scientific advice' - disembodied textual practices that are far removed from the 'messy', contaminating bodies that regulation seeks to control. Thus, underpinned by metrics delivered by SAGE (Scientific Advisory Group for Emergencies), the UK government has operationalised orderly, staged plans (e.g. the five level system of alert) and programmes (e.g. test and trace), setting out clear instructions on behaviour in order to 'reduce transmission', 'control the virus' and 'make progress' in terms of flattening the infection rate. As we are urged to 'wash hands thoroughly' and to refrain from 'coughing and spitting', one can see how this rational and disembodied performance of authority, order and regulation is seeking, in Douglas's terms, to control the physicality of the 'disordered, dangerous and contaminated other' - whilst at the same time provoking an emotional engagement through a language of 'safeguarding' 'protection' and 'support'.

Contamination therefore speaks to more than just a physical manifestation of infection and disease and carries strong traces of authority, power and control. In untangling some of these dynamics, we draw on Ashforth and Kreiner's (1999) typology of taint: physical taint involves direct contact with dirt or danger; social taint captures the implications of contact with stigmatised groups; while moral taint indicates lack of virtue or practices that 'defy norms of civility' (Ashforth and Kreiner, 1999: 415). In applying this typology to the 'gendering' of the Covid-19 pandemic and to notions of contamination more widely, we can see that the virus has a clear physical element through a bodily infection that is differentially encountered; that it involves the creation and maintenance of social boundaries separating the 'clean' from the 'contaminated'; and that it contains a moral aspect in terms, for example, of the negative judgements attached to people who transgress. With a focus on issues of inequality, privilege and disadvantage, we discuss each of these dimensions in more detail below. 


\section{'Gendering' Physical Contamination from Covid-19}

In early April 2020, at the height of the pandemic and days after the Prime Minister Boris Johnson was hospitalised and the Health Secretary diagnosed with the virus, the UK government was criticised for claiming that Covid-19 was 'a great leveller' hitting 'rich and poor alike'. As Cabinet Office minister Michael Gove told a press conference at the time: "The fact that both the prime minister and the health secretary have contracted the virus is a reminder that the virus does not discriminate" (Milne, 2020). As outspoken British journalist Emily Maitlis counterclaimed, "you do not survive the illness through fortitude and strength of character, whatever the prime minister's colleagues will tell us" (Milne, 2020). As evidence has subsequently shown, huge inequalities have opened up in terms of who has been infected and lost their lives from the virus, casting doubt on the 'leveller' hypothesis as above.

While age was acknowledged from the start as a major risk factor and while men are $57 \%$ more likely than women to die from the virus, it became evident early in the pandemic that people who are black or from an ethnic minority background (BAME) are at a higher risk. As a report from Public Health England (2020) concluded, people from BAME groups are twice as likely to die of the virus, potentially reflecting both health and racial inequalities in the UK. Preliminary research has suggested underlying health conditions as possible medical factors behind this disparity (Howarth, 2020). Differential availability of effective PPE (personal protective equipment) has also been proposed. Here, care workers in nursing homes with a high proportion of BAME employees and with poorer provision of PPE have been shown to be particularly vulnerable. Healthcare workers (including doctors, nurses and midwives) by contrast, equally exposed to the virus but who have greater access to protective equipment are no more likely than the general population to die from the disease.

These physical factors notwithstanding, occupation has emerged as a key factor behind levels of vulnerability towards Covid-19, with the impact of the virus exacerbated for those working in lower 
paid jobs which often cannot be done from home. As a report by Public Health England (2020)

found, men working in the lowest paid jobs have the highest levels of vulnerability. For both men and women, death rates are particularly high among carers, taxi-drivers, bus and coach drivers, shop workers and security guards (Public Health England, 2020) - 'people facing' jobs which involve close, physical contact with others and which are often conducted within closed spaces where the virus can more easily spread. Care workers face unprecedented pressures with half suffering mental health problems such as stress - linked mainly to inadequate PPE and anxiety for their own welfare and that of their families (Campbell, 2020). Tellingly, one in five of these workers are from BAME groups.

Therefore, while Covid-19 can be seen as a physical condition and while heavy reliance has been placed on scientific evidence and advice in combatting the disease, this suggests that physical factors alone cannot explain the differentials in terms of who is vulnerable and who has succumbed. In other words, there is a 'politics' to contamination through differential exposure and transmission. Here, some groups are vulnerable because they are more likely to be employed in 'high risk' sectors for infection. As we have seen, many low paid workers, often without the means, the opportunity or the protection of working from home, are 'on the front line' in terms of exposure to the disease and are highly vulnerable to contamination.

\section{Social Distancing and Contamination}

For Ashforth and Kreiner (1999), social taint involves contact with stigmatised groups or individuals, seen potentially as a source of contamination. With clear associations with the strategies surrounding Covid19, Douglas (1966) argues that 'social distance' enables the separation of the pure from the contaminated so that the effects of dirt can be contained. Here, adopting a similar terminology to Douglas above, key intervention strategies aimed at combatting the virus have been social distancing (e.g. prohibiting public gatherings, closing schools, keeping a distance of no less 
than two metres from others) and social isolation (remaining indoors except for a brief period of exercise) where the source of contamination is in the form of a potentially polluting 'other' body.

'Gendering' these practices is to highlight how, while men are at greater risk from the disease, women and the low paid suffer in different ways. In terms of the former, lockdown has meant that women are being forced back into a domesticity that they thought they had escaped. With the closure of schools and nurseries and family members isolating in one location, it is women who are shouldering the greater burden of domestic responsibilities including childcare and home schooling with negative implications for work, especially as they are less likely to work from home. Further, given that those in lower paid employment, such as female dominated retail and hospitality, are more likely than the higher paid to lose their jobs or be furloughed (30\% and $3 \%$ respectively, Judge, 2020), women's contribution to the household may be seen as less significant, intensifying expectations that women take on the domestic role.

Social isolation creates other, more serious, pressures. As has been widely acknowledged, 'lockdown' can be a dangerous condition for women. Domestic violence incidents have increased by 9\% compared to the previous year, with the London based Metropolitan Police making 100 arrests a day (Snuggs, 2020). The support charity Refuge has reported a $25 \%$ increase in call and on-line requests for help since the lockdown started. These risks to women are not unique to the UK but have been reported world-wide including China, Italy and Spain (ibid).

Creating boundaries between the 'clean' and the source of pollution (Douglas, 1966) through social distancing from the potentially contaminating 'other', is accordingly shaped by gender and class. For example, low paid workers are more likely to be 'space poor' with limited access to gardens and outdoor facilities. Given that the virus is more likely to spread in crowded condition, it is no coincidence that in Hackney, one of the poorest areas of London, the death rate from Covid-19 is almost double that of more affluent areas. Social distancing and isolation have accordingly disproportionately affected women and those in low paid or precarious employment through social 
and economic losses (income, routines, independence and autonomy) with the strategies to control the virus arguably hitting women and the most deprived communities hardest.

\section{Moral Contamination and Violation of the Lockdown Rules}

In the last week of May 2020, at the height of the pandemic in the UK, a story drew international criticism for its seemingly unashamed display of double standards on the part of the political elite. Dominic Cummings, senior aide to the Prime Minister was found to have travelled with his symptomatic wife, in clear breach of the lockdown rules, 240 miles from his home in London to his parent's house in Durham in order to arrange childcare for his son. Moreover, it emerged that he had later taken a detour to visit a local beauty spot, claiming as justification that he was 'testing his eyesight' for the long journey home - a story that was generally greeted with disbelief. Supported by the prime minister, he refused to resign. Under the heading 'Beyond an Insult: Fury of those who Stuck to Lockdown Rules', Ben Quinn and Sarah Marsh of The Guardian newspaper captured the general mood of anger and outrage from the public, many of whom were "mourning loved ones" including "parents of newborns who had found themselves unable to draw on family support" and who had made "personal sacrifices...in order to keep within lockdown rules" (Quinn and Marsh, 2020).

This episode speaks powerfully to issues of elitism and moral taint in the context of Covid-19, as well as to contrary notions of sacrifice and 'purity'. Moral taint occurs when an individual's moral record has been compromised through actions that are widely seen to be negatively judged and/or seen to be of a dubious virtue, amply exemplified by the Cummings saga above. The scale of the violation must be set against a background, as Williams et al (2020) found, of a generalised public adherence to the lockdown rules on the grounds of social conscience, despite the many difficulties and sacrifices involved. Not surprisingly, condemnation has been widely expressed towards those who have been seen to transgress, thereby putting the lives of other at risk. While this has included localized breaches of social distancing, for example at sea-side resorts and other public spaces, more 
damaging, highly publicized cases have involved people in positions of power. For example, epidemiologist Professor Neil Ferguson, whose modelling helped to shape the Lockdown strategy in the UK, resigned after receiving visits from his lover at his home in contravention of the lockdown rules, adding to the sense that the rules are being 'arrogantly dismissed' by the political elite (Ashworth, 2020).

As Douglas (1966) argues, drawing on Christian doctrine, the interrelated elements of sacrifice and purity are ritualised in symbolic systems. In the context of Covid-19, while the newly imposed systems of control have a clear material basis, they also contain a symbolic element through the notion of sacrifice, as people are presented as foregoing family contact and/or as working 'on the front line' at personal cost 'for the greater good'. The latter is exemplified through the weekly ritual of 'clap for carers', where people came onto their balconies and front doorways to express gratitude for the sacrifice and dedication of NHS and care staff as they put themselves at risk. As Health secretary Matt Hancock proclaimed: "A huge THANK YOU to our incredible NHS and social care staff. We can never thank you enough for all that you are doing for the nation."

Set against these attitudes and practices that simulate a sacrificial purity, often associated tellingly with low-paid front-line staff who are at greatest risk, the Cummings affair and other instances of high -profile contravention can be seen as a form of defilement. For Douglas (1966), notions of dirt and impurity are grounded in anomalies namely, that which deviates from what is normal or expected, violating an order or classification. In 'offending' against the lockdown rules, Cummings not only contravened a system of virus containment, but also undermined the consistency with which the rules were seen to apply. Separate consideration and license, based on notions of entitlement, were seemingly given to the behaviours of the elite. Purity can accordingly be seen in the sacrifices made 'for the common good' in containing the virus, particularly, in extremis, from the many low-paid workers on the 'front-line' who have lost their lives. This puts into sharper focus the 
moral taint attaching to behaviours that 'offends against order', conceptualised by Douglas as contamination, pollution and 'dirt'.

\section{Concluding Remarks}

We have sought to explore the 'gendering' of contamination in the context of Covid-19. In so doing, drawing on an established conceptualisation of physical, social and moral taint, we have highlighted key inequities in the physical exposure to and transmission of the disease; how the effects of social distancing and social isolation are shaped by gender and class; as well as how, set against the 'moral purity' of personal sacrifice, elite practices of non-compliance and attitudes of entitlement can be seen as a form of defilement and moral taint.

As this suggests, there is a politics of contamination that builds on and reinforces existing social and economic inequalities, going beyond the simple physicality of the disease. Here, the pandemic has brought inequalities into sharp focus, exposing structural disadvantage and discrimination as well as potential 'double standards' in terms of the sacrifices made. As our example of Typhoid Mary showed, and as highlighted in our application of physical, social and moral taint, contamination builds on and reproduces classed, gendered and racial difference. We can accordingly see the devastating effects of contamination on groups of vulnerable workers who are glaringly essential to our daily lives and well-being. The common mantra from the government and elsewhere with respect to the pandemic: 'We are all in this together' rings hollow when some groups are evidently more susceptible than others and bear a greater cost. It remains to be seen whether the gratitude hitherto expressed in the form, for example, of 'clap for carers' translates into greater value given to the work undertaken by these groups post Covid-19. 


\section{References}

Ashforth, B. and Kreiner, G. (1999) 'How can you Do it? Dirty Work and the Challenge of Constructing a Positive Identity', Academy of Management Review: 24 (3): 413-434

Ashworth, J. (2020) One Rule for Johnson's Elite Friends, Labour List:

https://labourlist.org/2020/05/one-rule-for-johnsons-elite-friends-another-for-the-rest-of-usashworths-covid-19-update/, accessed 8.6.20

Campbell, D. (2020) Half of UK health workers suffering stress because of Covid-19, The Guardian, April 23rd

Douglas, M. (1966) Purity and Danger: An Analysis of Concepts of Pollution and Taboo, London: Routledge and Kegan Paul.

Höpfl, H. (2012) Dirty Work and Acts of Contamination, R. Simpson, N. Slutskaya, P. Lewis and H. Höpfl (Eds) Dirty Work: Concepts and Identities, Basingstoke: Palgrave, pp 19-32

Howarth, M. (2020) Vitamin D deficiency linked to risk, The Times, May $18^{\text {th }}$

Judge, L. (2020) Coping with housing costs during the coronavirus crisis, Resolution Foundation, May Karyotis, G. (2020) British people blame Chinese government more than their own for the spread of the virus, The Conversation, May $6^{\text {th }}$

Lay, K. (2020) Infections imported from Italy and Spain, Lords told, The Times, 3.6.2020

McClintock, A. (1995) Imperial Leather, London: Routledge

Milne, A. (2020) UK under Fire for Suggesting Coronavirus 'Great Leveller', Reuters, April $9^{\text {th }}$ Public Health England (2020) Disparities in Risk and Outcomes of Covid-19, PHE publications 
Quinn, B. and Marsh, S. (2020) Beyond an Insult: Fury of those who stuck to lockdown rules, The Guardian, May $25^{\text {th }}$, pp 36

Simpson, R., Slutskaya, N., Lewis, P, and Höpfl, H. (2012) Introducing Dirty Work, concepts and Identities, R. Simpson, N. Slutskaya, P. Lewis and H. Höpfl (Eds) Dirty Work: Concepts and Identities, Basingstoke: Palgrave, pp 1-18

Snuggs, T. (2020) Coronavirus: 4,000 domestic abuse arrests in London in just six weeks, police say, https://news.sky.com/story/coronavirus-4-000-domestic-abuse-arrests-in-london-in-just-six-weekspolice-say-11978358, Friday $24^{\text {th }}$ accessed 8.6 .20

Williams, S., Armitage, C., Tampe, T., and Diene, K. (2020) Public perceptions and experiences of social distancing and social isolation during the COVID-19 pandemic: A UK-based focus group study, available at https://www.medrxiv.org/content/10.1101/2020.04.10.20061267v1 